\title{
Reflections on China-US relations after the COVID-19 pandemic
}

\section{Nansheng Yuan ${ }^{1}$}

Received: 21 June 2020 / Accepted: 19 July 2020 / Published online: 3 August 2020

(C) The Institute of International and Strategic Studies (IISS), Peking University 2020

\begin{abstract}
China-US relations are the most important bilateral relations in the world. Today, China-US relations are neither the same as then Soviet-US relations, nor as their previous situation. After the breakout of COVID-19 Pandemic, China-US relations show great differences in terms of public opinions, economic and trade relations and strategic trust. It is of great importance to keep sober minded about China-US relations after the outbreak of COVID-19 pandemic and to uphold Deng Xiaoping's guiding principle of "hiding your strength and biding your time while trying to accomplish something", which are essential for China to deal with various severe challenges under the new circumstances and to safeguard China's security and development environment.
\end{abstract}

Keywords China-US relations · Globalization · COVID-19 · International order

\section{Introduction}

At the meeting of the Standing Committee of the Political Bureau of the Central Committee of the Communist Party of China on April 8, 2020, it was pointed out that "in face of the grave and complex COVID-19 pandemic and global economic landscape, we must be prepared for the worst-case scenario and tackle the changes in the external environment in the long run, both in work and in mind" (Xi 2020). From my understanding, "the changes in the external environment" mainly refers to the changes in China-US relations. As the most important bilateral relationship in the world, it is a pillar for contemporary international order. Having a clear understanding of the China-US relationship after the COVID-19 pandemic is crucial to address the daunting challenges under new circumstances, to maintain a sound

Nansheng Yuan

yuannansheng@163.com

1 China National Association for International Studies, No. 24, Zhanlanguan Road, Xicheng District, Beijing, China 
environment for China's security and development, and to realize the "two centennial goals".

\section{There is no going back for China-US relations}

In early April, Henry Kissinger forecast in his article that the COVID-19 pandemic would forever alter the world order (Kissinger 2020). Before that, he said there is no going back for China-US relations, and there is some truth in what he said. The evolvement of China-US relations is in tandem with the world order. The impact of the pandemic on world order is, to say the least, found in the following aspects: globalization has somewhat turned into de-globalization; the strategic cooperation between China and the US has shifted to a so-called strategic rivalry in US terms; the decades-long period of China's strategic opportunity has turned into de-Sinicization, which is the essence of de-globalization; and the international division of labor that featured mutual complementarity has transformed into international cooperation with shared political values. As the US withdraws from major international organizations, the World Trade Organization (WTO) and World Health Organization (WHO) may become weaker and less tangible. Further, the US and its allies may start new international regimes that exclude China, thus challenging the Yalta system marked by the UN.

\subsection{China-US relations are starkly different from Soviet-US relations}

During the Cold War, the USSR and Eastern European countries established a socialist bloc, and their planned economies were based on the enclosed circle of the Council for Mutual Economic Assistance. By contrast, in the capitalist bloc, comprised of the UK, the US, and other countries, market economies operated through the General Agreement on Tariffs and Trade. Today, China and the US have established an historical record of trade and economic exchange in the WTO system. Since the two countries established formal diplomatic relations in 1979, their bilateral trade in goods has witnessed a 207-fold increase, reaching nearly USD 600 billion a year, and their bilateral trade in services has reached USD 100 billion. China benefits hugely in terms of exports, employment, technology, and talent, and it has also become America's fastest growing overseas market: the US exports $26 \%$ of Boeing airplanes, $56 \%$ of its soybeans, $16 \%$ of its automobiles, $23 \%$ of its agricultural products, and $23 \%$ of its integrated circuits to China. China is the largest export market for America's planes and soybeans, and the second largest export market for its agricultural products, automobiles, and integrated circuits. In addition, China has a services trade deficit with the US, which generates huge economic returns for the US in tourism and education. China's non-financial investment in the US reached USD 50 billion in 2016, covering 44 states and creating 100,000 jobs. The stakes of China-US trade and economic relations are much higher than those of Russia-US relations. For instance, the annual volume of goods trade between China and the US is nearly USD 600 billion now, compared with only USD 15 billion in goods trade 
between Russia and the US, and Russia and the US are competitors in energy and other sectors. The scale of the Russian economy is incomparable to that of China: Russia's GDP is currently only equivalent to that of Guangdong Province. Russia's lack of economic and trade weight is the most important reason for why the US and other Western countries dare to impose collective sanctions on Russia.

\subsection{The current China-US relationship is much different from what it used to be}

The China-US relationship has gone through four stages: from outright enemies to adversaries, partners, and now back to adversaries again. The stage of adversary refers to the hot war period, i.e., the Korean War (1950-1953). The stage of rivalry refers to the period during the Cold War before the establishment of China-US diplomatic ties, when US policy toward China was containment. The stage of joining hands refers to the period between the establishment of China-US diplomatic relations (1979) and Trump's entry into office (2017), when US policy toward China, especially after the September 11th, 2001 attacks, was engagement. At present, the bilateral relationship has returned to rivalry. Though two stages of the China-US relationship are called rivalry, they are not exactly the same. In the previous stage, the US regarded China only as a normal adversary, rather than a full-on strategic competitor. In the current rivalry stage, according to the US, the two countries are strategic competitors. Trump and other American politicians regard China as a revisionist state, implying that China is dissatisfied with the US-led international order and, thus, hopes to revise the status quo. The US response has been to launch a longterm, all-dimensional strategic competition against China with a whole-of-government approach.

\subsection{China-US relations before and after the COVID-19 pandemic will be largely different}

The first difference in China-US relations before and after the COVID-19 pandemic is in public opinion. Some overseas polling agencies suggest that in both countries, the number of people who hold negative views of the other country is rising markedly and has become the majority. The goodwill of the US public toward China has continuously declined, reaching the lowest mark of this century and one of the historic lows of the entire 40-year diplomatic relationship.

The second difference lies in economic and trade ties. Though the trade war has been suspended since the Phase One trade deal reached in January 2020, problems between the two sides have not been fundamentally addressed, as the US has failed to lift the high tariffs it imposed on China before the deal. The pandemic may accelerate the withdrawal of the US capital from Chinese markets, and both sides lack the will to further invest in each other.

The third difference is declining cooperation across certain fields. Chinese will be less passionate about travel, study, migration, and stage performances and exhibitions in the US. 
The fourth difference is diminishing mutual strategic trust, which is the most significant change and almost irreversible. In the future, the US will impose greater pressure on China in terms of trade ties, technological competition, cybersecurity, and issues related to Taiwan, Hong Kong, Tibet, and Xinjiang.

Some may argue that the COVID-19 pandemic will accelerate de-globalization and that the "New Cold War" will speed up China-US decoupling. Is that possible? America's policy toward China in the aftermath of the pandemic may shift to containment, and while the possibility of a "New Cold War" and decoupling is slim, it cannot be ruled out. These risks remain to be seen and should not be taken lightly.

The so-called "New Cold War" refers to the decoupling of China and the US, including the decoupling of science and technology, investment, industry, education, and talent. America is indeed working on decoupling, but will it really happen? I do not think so. I was appointed Chinese Consul General to San Francisco in 2013, and during my term, there was a flight between the two countries every $7 \mathrm{~min}$. More than 10,000 travelers per day, and 4 million passengers per year, traveled between the two countries. Chinese tourists spent an average of USD 6000 in America. The two countries were incredibly interdependent: in San Francisco, around a quarter of citizens were Chinese Americans, and in the consulate district, there were more than 12,000 and 7000 graduates from Tsinghua University and Peking University, respectively. It will be difficult for China and the US to fully decouple, but engagements, exchanges, and interactions between the two are very likely to be less frequent than before. As long as economic and trade exchanges continue, the two countries will not decouple. The scale of bilateral trade is too great, industrial and supply chains too connected, demand for Chinese capital too high, interdependence in high-tech too deep, people-to-people exchange too frequent, and the impact of China-US macroeconomic coordination on the global market too massive. If China and the US truly decouple, it will surely cause huge chaos in the international order. Further, decoupling will implicate each and every aspect of the relationship, and will be a complicated, exhausting, and even painful process. Therefore, decoupling will not happen easily.

During the global pandemic, the US has not sent enough signals of solidarity and cooperation, nor the will or ability for global leadership. It is in trouble because of its own failed response, yet it still tries to blame China. The US government's status and conduct are certainly not in China's interest. As the epicenter of the pandemic, the US's number of cases and death toll rank as the world's highest. Trump is engulfed in controversy and is blamed both domestically and internationally. As the US presidential election is approaching, there has been a flareup in irrational rhetoric, which often involves the "China issue". Facing the risk of low support, Trump's efforts to be reelected may be going down the drain. As a result, he has turned to China's earlier handling of COVID-19 to divert domestic attention and stabilize his support, leading to the poisoning of public opinion in both countries.

After the epidemic, globalization will not be interrupted, but it may take another approach. The old version of globalization stressed cost advantages to realize an international division of labor, while the new one is very likely to emphasize uniform political values to alienate and undercut China. Nevertheless, without China, there will not be true globalization nor a holistic world market. As a major 
manufacturer, trade partner, and market, China can fully draw on its advantages and overcome its shortcomings, so as to defend and expand the breadth of its interests.

\section{China-US relations need to maintain stability}

On April 6, 2017, President Xi Jinping met with President Trump at the Mar-a-Lago estate in Palm Beach, Florida. During the meeting, President Xi (2017) stressed:

...good China-US relations are not only in the interest of the two countries and their people, but also the rest of the world. There are a thousand reasons to make the China-US relationship a success, and not a single reason to break it. Since the two nations normalized diplomatic ties 45 years ago, though the bilateral relationship went through ups and downs, historic progress has been made, which has generated tremendous gains for our people. How China-US relations will evolve in next 45 years is thought-provoking, requiring both our leaders to show political determination and take historic responsibility. I'm ready to work with you, Mr. President, to make further progress in China-US relations at the new starting point.

On the morning of June 29, 2019, the two presidents met in Osaka, Japan. President Xi (2019) said:

China and the United States both benefit from cooperation and lose in a confrontation. Cooperation and dialogue are better than friction and confrontation. At present, bilateral relations have encountered difficulties that are not in the interest of both sides. Though we have disagreements, our interests are so interdependent and scope of cooperation so broad that we mustn't fall into the trap of conflict and confrontation, but instead should help each other and seek common development.

Stabilizing China-US relations is helpful for a stable international order. The level of stability in China-US relations is proportionate to the well-being of the Chinese and American people and to the stability of the international order. Why?

Telling from Mao Zedong and Deng Xiaoping's diplomatic philosophies and practices, they both highly valued China-US relations and worked on them themselves. Mao's "leaning to one side" anti-US diplomacy changed into "one line" diplomacy that worked together with the US, which significantly expanded the room for China's diplomacy and changed the global landscape. Shortly after Deng Xiaoping's return from the Cultural Revolution, he became the principal assistant to Premier Zhou Enlai in diplomatic affairs, especially with regard to establishing diplomatic relations with the US. He took over China-US relations in times of difficulty and normalized the relationship through maneuvers, fostering the external environment essential for China's reform and opening up. Stabilizing China-US relations is in line with Mao and Deng's last wishes.

Judging from thousands of years of China's diplomacy, stabilizing China-US relations is an integral part of acting as per the laws of history and developing the 
major country diplomacy of socialism with Chinese characteristics in a new era. Laws developed over the last thousands of years of China's diplomacy include: do not challenge the most powerful country, do not confront multiple countries, avoid special forms of diplomatic relations, more open policies make greater room for diplomacy, national interest trumps all other interests, hide your strength and bide your time, and so on. It is known to all that betraying the laws of history may cause trouble. Take "do not challenge the most powerful country" as an example. Before the founding of the People's Republic of China, the country had never confronted any superpower head-on. The Opium War was not the result of China's provocation of the UK, but of the UK's aggression against China. As a result of the war, GUO Songtao went to the Great Britain as an envoy, and China thus integrated into the Western treaty system. In both World Wars, China sided with the most powerful country, both of which emerged victorious. In particular, the People's Republic of China emerged through the diplomacy of the Chinese People's War of Resistance against Japanese Aggression, which involved both the Communist Party of China and the Kuomintang. At the Cairo Conference, similar to the US's support of China's reclamation of its right to Shandong from Germany after World War I, President Roosevelt supported the return of all the territories occupied by Japan (Manchuria, Taiwan, the Penghu Islands, etc.) to China. By joining hands with the world's superpower, the US, China became a founding member of the United Nations and a permanent member of the UN Security Council, reclaimed Taiwan and other concessions, abrogated unequal treaties, achieved tariff autonomy, and established itself as a major power. In 1943, at the Cairo Conference and the Tehran Conference, Stalin and Churchill strongly opposed making China a permanent member of the UN Security Council. Stalin finally gave in because the American representative threatened to leave the meetings. When China's relations with the world's major powers were troubled, it suffered higher diplomatic cost, reduced diplomatic space, and less diplomatic leeway. Otherwise, the diplomacy yielded greater dividends. For instance, after President Nixon's first visit to China and the establishment of China-US diplomatic ties, a multitude of countries chose formal relations with the mainland over Taiwan, and China's room for diplomacy grew significantly over a short period. Mao Zedong in his late years acutely realized the importance of not challenging the most powerful country and invited Nixon to visit China, thus initiating the normalization of bilateral relations and the end of China's challenge to the superpower. China's reform and opening up is mainly due to normalization with the US.

From a geopolitical perspective, China, the US, and Russia form the world's most important triangular relationship. The US and Russia have long been competing for hegemony, and China as a lever, is in a good strategic position. If China-US decoupling happens, the roles of China and Russia will switch, making China the primary target of US containment and undercutting. Russia will become the lever welcomed by both sides and profit from the competition between the other two. Decoupling also means that China will stand out, which will reduce its diplomatic initiative and flexibility, increase its diplomatic costs, and reduce its diplomatic returns. Some say China can join hands with Russia to counter the US, which is not quite sensible. In international relations, countries are neither friends nor enemies permanently. If the decoupling truly happens, will the US draw Russia to its side? Will Russia embrace 
the US? Will Russia-US and China-Russia relations change? We need to think about all sorts of possibilities.

When it comes to building a community with a shared future for mankind, would not it be an embarrassment if the world's two biggest economies cannot even cooperate for win-win results after decoupling?

How can we stabilize China-US relations? First, we should keep a clear mind and recognize that we are still in an era of peace and development and that we are still a developing country in the early stages of socialism. Second, we should maintain strategic patience to prevent hastiness. Third, we should defend our strategic bottom line, bide our time, and work hard. Fourth, we should prevent strategic miscalculation, especially concerning the US. It would be a mistake to interpret China's actions as competing for hegemony or to assume that the US is declining, that its problems during the fight against the pandemic reveal its diminishing hegemony, that another country should replace the US to take global leadership, or that China - as the first country to suffer and overcome the pandemic - faces an historic opportunity to compete with the US for hegemony. Compared with itself, America is still developing, not declining. Over the last hundred years, its economy has accounted for a quarter of the global economy, and is likely to continue to do so in the foreseeable future. It will continue to boast hegemony in science and technology, military affairs, and finance. It will remain the most powerful country in geopolitics, agriculture, education, science and technology, and resources. Regarding agriculture, despite having an agricultural population of less than 3 million, it is the world's largest food exporter, accounting for half of the world's total exports. China is the world's largest food importer. The size of the total US economy exceeds USD 20 trillion, and only China, India, Vietnam, and Ethiopia are growing faster than the US. The US's influence and sway are declining mainly due to the rise of China and other emerging countries, as well as its soft power induced by unilateralism and American supremacy. The COVID-19 pandemic has dealt a heavy blow on US economy, but this does not equate to a major opportunity for China's economic development. The economic hardship of either China or the US will have a negative impact on the other and the rest of the world. As the US has top-notch science and technology, the world's biggest consumer market and financial market, and the world's reserve currency, it is likely to be the first to overcome its economic difficulties and get back on track.

It goes without saying that stable China-US relations cannot happen with only one party's effort; it requires both China and the US to work together. China must comprehensively evaluate its relations with the US, and though it will not try to go separate ways, it must also be prepared for the future uncertainties if the US becomes an enemy.

\section{Biding our time and working hard}

We should be proud of China's performance in tackling the COVID-19 pandemic, but it would be a strategic miscalculation to predict the pandemic to be an "historic opportunity" for China's emergence. People with insight have reasons to worry that the pandemic may fuel China's nationalism at home. Trump advocates "America 
First", which the international community generally sees as pandering to America's populism, unilateralism, and extreme nationalism. If China's populism and extreme nationalism are left unguarded and unchecked, the world may misinterpret it as "China First".

In recent years, extreme nationalism and populism have become louder internationally. Trump became US President by calling for "America First", which is the product of populism. Such sentiments are also often felt in China, and were called "angry youth culture" earlier and are now termed "wolf warrior culture". It is not strange for extreme nationalism and populism to occur in China, because their existence and development have deep roots in history and culture and fit in with reality:

First, China's extreme nationalism and populism are influenced by the Sinocentrism, or tianxia. For thousands of years, Sinocentrism, which stemmed from the high self-esteem of the Chinese nation and the belief that China was the center of the world (Huaxia) both geographically and culturally, dominated China's diplomacy. The invasion of Western powers deeply shocked Sinocentrism, and China's military defeats forced it into the modern world system. The traditional Hua-Yi order and notion of Celestial Empire gradually collapsed and China ceased to be the center of the world. Sinocentrism lost its sway and was replaced by emerging nationalism as a new spiritual bond.

Second, China's extreme nationalism and populism are influenced by the punishment theory: those who attack the Chinese nation, no matter how far they are, must be punished. For some people, their temperament flares up easily if there are differing views in diplomatic exchanges. As a result, occasions that are meant to be dialogs become replaced by shouting matches or even singling out.

Third is the influence of triumphalism, which argues that since China's system is better than that of the West, America is in decline, and China has become the second largest economy and has never been closer to the center of the world arena, it will not take long for China to naturally replace America as the world's superpower.

Fourth is the influence of the there-must-be-a-war theory: "There must be a war between China and America/Japan/India/the ROK/the Philippines". Those words have been frequently heard in recent years, and some people simply equate war with patriotism.

Public opinion cannot simply be equated with extreme nationalism and populism. Successful diplomacy makes good use of public opinion, making it a useful tool for diplomatic exchanges. However, extreme nationalism and populism in the disguise of patriotism can easily instigate and take advantage of public opinion, and in turn, take control of diplomacy. Traditional Chinese culture advises that one should remain calm when facing a sudden event and refrain from anger when wronged by others. Nevertheless, the "wolf warrior spirit" contradicts traditional Chinese culture, making it irrational. The degree to which diplomacy is coerced by public opinion is inversely proportional to the amount of diplomatic space. The louder the voices of extreme nationalism and populism, the greater the impact will be. As a result, confrontation more easily replace dialogue in foreign relations, and China will have fewer and fewer friends.

To avoid blind nationalism, we must first spread knowledge, reaffirm common sense, avoid information asymmetry, and help people could better understand 
history. In some cases, nationalism is related to information asymmetry and narrowmindedness. For example, we can certainly be proud that China has the second largest economy, but some people have become too complacent and call out everywhere, "what a powerful country!" This can be problematic. The fact is, China's GDP was the world's second largest in 1900, when it was invaded by the Eight-Nation Alliance. In 1927, it was the third largest, and in 1949 the fourth largest. According to the famous economic historian Angus Maddison (2003), in the first year of the Common Era, China's GDP was second only to India, which then was also composed of Pakistan, Kashmir, Bangladesh and Sri Lanka. In 1500, during the Ming Dynasty, China overtook India as the world's biggest economy. For thousands of years, China was the world's most qualified second largest economy, since it has been there three times: once before the Ming Dynasty, once in modern history before being overtaken by the UK, and now. Having this knowledge helps us to keep a clear mind. Second, we should improve guidance and thinking patterns and avoid viewing problems with simplification, labeling, and emotionalization, such as equating smashing Japanese cars with patriotism. Third, we must defend the bottom line-for instance, by not gloating at the British Prime Minister for contracting COVID-19 or celebrating the fact that the US has become the country with the most COVID-19 cases and tens of thousands of deaths.

It is good that many people are interested in diplomacy, and letting professionals handle diplomatic issues is not contradictory to people's attention. The more mature, rational, and open to information people are, the more room there will be for diplomacy. On the one hand, in the era of self-media, diplomats should understand and respect public opinion, because doing so aligns with the practices of global diplomacy and it is the principle of Chinese diplomacy to serve the people. But on the other hand, we should not listen solely to public opinion. It has been proved countless times that if diplomacy is coerced by public opinion, disastrous consequences will ensue. For example, in 1917, after the October Revolution, Lev Karakhan, the Deputy Commissioner for Foreign Affairs under Soviet Russia, issued the Karakhan Manifesto, which offered to unconditionally relinquish territory obtained from China. Adolph Abramovich Joffe, an alternate member of the Central Committee Secretariat of the Communist Party of the Soviet Union and the Deputy Commissioner for Foreign Affairs, came to China to negotiate the establishment of diplomatic relations, hoping that doing so would help mitigate mounting pressure from the UK. V. K. Wellington Koo, the Foreign Minister of the Beijing Government, told Joffe that the two countries could immediately establish diplomatic relations once Soviet Russia withdrew its army from Outer Mongolia. However, university students in Peking held demonstrations demanding unconditional diplomatic relations. They declared that if Koo did not agree, they would burn down his house like they burned down CAO Rulin's during the May Fourth Movement. Despite the threat, Koo refused their request, saying that it would be wrong to establish diplomatic relations while Soviet Russia still occupied massive amounts of Chinese territory. Later, a parcel was mailed to Koo's family and exploded upon opening. Yet Koo still refused to concede. People failed to understand that the Karakhan Manifesto was merely a diplomatic gesture, never meant to be and indeed never was implemented. Afterwards, Joffe flew to Shanghai and issued the Sun-Joffe Manifesto with Sun Yat-sen. 
In it, Soviet Russia promised to help the Kuomintang and Sun, in turn, agreed that Soviet Russia did not need withdraw from Outer Mongolia, thus planting the seed of Outer Mongolia's split from China. History proved Koo was right. Ordinary people are not diplomats - catering or even pandering to public opinion may harm the interests of the state, and ultimately the interests of the people.

To stabilize China-US relations, we must uphold Deng Xiaoping's guiding principle of "hiding your strength and biding your time while trying to accomplish something", which is still relevant and applicable. As long as China is a developing country in the early stages of socialism, this principle is essential. "Hiding strength and biding time" does not mean one should be too soft, but instead implies that one should be tough if the situation requires it. It is like putting a sword into a sheath. In diplomacy, "hiding strength and biding time" means adopting a humble approach to interact with others instead of being aggressive and pushy. Some people say that keeping a low profile makes one a coward, which is completely mistaken. How do people feel if you hold a knife when communicating with them? Drawing a sword is a soldier's responsibility; diplomats should bide their time and put their swords into sheathes-people will still know of the swords' existence. Koo addressed everyone in a respectful way because diplomacy is not about shouting loudly or drawing a sword, but about making sense. During the Song Dynasty, WANG Lun visited the Jin Empire four times, and at the negotiation table, he took back more territory than any of the famous generals, such as YUE Fei. This was due to his smart negotiation, not quarrelling. It is natural and good that people argue about the principle of "biding time". China's diplomacy should be stronger instead of merely tougher, because when a country with strong diplomacy must lower its profile, it does so moderately; when it must ask for favors, it does so properly; when it must adopt strong terms, it toughens up; and when it must undertake a task, it does so brilliantly.

\section{Compliance with ethical standards}

Conflict of interest The author declares that there is no competing interests.

\section{References}

Xi, Jinping[习近平]. 2017. There are a thousand reasons to keep good relations between China and the United States (有一千条理由把中美关系搞好). https://theory.people.com.cn/n1/2018/0104/c4161 26-29746003.html. Accessed 24 Apr 2020.

Xi, Jinping[习近平]. 2019. Xi Jingping meets US President Trump (习近平同美国总统特朗普举行会 晤). https://www.xinhuanet.com/2019-06/29/c_1124688101.htm. Accessed 24 Apr 2020.

$\mathrm{Xi}$, Jinping[习近平]. 2020. Stick to bottom-line thinking, be prepared to deal with changes in the external environment for a long time (坚持底线思维 做好较长时间应对外部环境变化的准备). https:// www.mofcom.gov.cn/article/i/jyj1/e/202004/20200402954380.shtml. Accessed 24 Apr 2020.

Kissinger, Henry A. 2020. The coronavirus pandemic will forever alter the world order. The Wall Street Journal. https://www.wsj.com/articles/the-coronavirus-pandemic-will-forever-alter-the-world-order -11585953005. Accessed 24 Apr 2020.

Maddison, Angus. 2003. The world economy: a millennial perspective. Trans. Xiaoying Wu. Beijing: Peking University Press. 